\title{
Foot and Mouth Disease (FMD) among Animals in Nepal
}

\author{
Pratiksha Parajuli1 $^{*}$, Sudiksha Pandit 1 , Krishna Kaphle ${ }^{2}$ \\ ${ }^{1}$ Paklihawa Campus, Institute of Agriculture and Animal Science, Tribhuvan University, Siddharthanagar-1, Rupandehi, Nepal \\ ${ }^{2}$ Department of Theriogenology, Paklihawa Campus, Institute of Agriculture and Animal Science, Tribhuvan University, Siddharthanagar-1, \\ Rupandehi, Nepal
}

\section{Article Information \\ Received: 15 February 2020 \\ Revised version received: 14 March 2020 \\ Accepted: 17 March 2020 \\ Published: 29 March 2020 \\ Cite this article as: \\ P. Parajuli et al. (2020) Int. J. Appl. Sci. Biotechnol. Vol 8(1): 7-13. DOI: $10.3126 /$ ijasbt.v8i1.27785}

\section{*Corresponding author}

Pratiksha Parajuli,

Paklihawa Campus, Institute of Agriculture and Animal Science, Tribhuvan University, Siddharthanagar-1, Rupandehi, Nepal

Email:prateekxa29@gmail.com

Peer reviewed under authority of IJASBT

(C) 2020 International Journal of Applied Sciences and Biotechnology

\section{QPEN ACCESS}

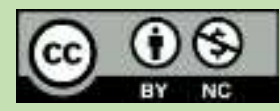

This is an open access article \& it is licensed under a Creative Commons Attribution Non-Commercial 4.0 International (https://creativecommons.org/licenses/by-nc/4.0/)

Keywords: Apthovirus; FMD; Livestock; Nepal; Serotypes

\begin{abstract}
Foot and Mouth disease (FMD) is a highly contagious viral disease, affecting all domestic as well as wild cloven-hoofed animals caused by Apthovirus of Picornaviride family. FMD is endemic in Nepal causing substantial economic losses to livestock industry mainly cattle and buffalo, directly by decreasing the production and change in herd structure, and indirectly losses by cost of FMD control. The predominant serotype responsible for endemic outbreak of FMD in Nepal is ' $\mathrm{O}$ ' however serotypes ' $\mathrm{A}$ ' and 'Asia-1' have also been detected. Peak level of occurrence is noticed during pre-monsoon (April - May) and postmonsoon (Oct-Nov) period, however it occurs throughout the year. Movement of animals within the country mainly during festival season, illegal trading of livestock between Nepal and India because of open border, poor knowledge about the disease among farmers, high cost of treatment and control, lack of strict quarantine practices are the major factors contributing to high frequency of outbreak. Cattles were most frequently affected followed by buffalo, goat, sheep and pig. The objective of this paper is to evaluate the current scenario of FMD in Nepal, its transmission, diagnostic approaches and prevention and control measures. This paper is based on review of different articles from various journals, magazines, epidemiological bulletin, and reports from government of Nepal. The present approach to control this disease is through the vaccination of animal by imported multivalent vaccines. Vaccinations based on the matching of a vaccine strain to a field strain can be a better approach.
\end{abstract}

\section{Introduction}

Foot and Mouth Disease is a highly contagious viral disease affecting all cloven-hoofed animals caused by single stranded RNA virus, FMD virus (genus: Aphthovirus, Family: Picornaviridae). Seven serotypes of FMD virus have been known, namely, A, O, C, SAT1, SAT2, SAT3 and Asia 1 (Grubman and Baxt, 2004). It is characterized by fever, vesicular eruption and blister formation in the epithelium of oral cavity, nares, tongue, muzzle, between hooves, teats and udder (Chakrabarti, 2012). Morbidity rate is high and mortality is low. There is the focal degeneration of skeletal and cardiac muscles leading to death in young calves( Adhikari et al., 2018)

It is endemic in Nepal causing substantial economic losses in the livestock sector ( Adhikari et al., 2018) primarily due to the reduction in milk and meat production and secondarily due to the higher cost in controlling the disease and loss of draught power. Annual economic loss due to reduction in production of milk and meat was estimated to be around 66 million US dollar (Gongal, 2002). Out of 
seven different serotypes of FMD virus, serotype $\mathrm{O}, \mathrm{A}$ and asia-1 are predominant in Nepal. It is included in FMDV pool 2, in which serotypes $\mathrm{O}$ is most prevalent followed by A, and Asia-1 (Brito et al., 2017). However serotype C was present in Nepal in ancient time (Ferris et al. 1992), but it has not been detected since 1996 (Jha, 2012; Adhikari et al., 2018).The vaccination against one serotype does not provide cross protection against other (Jamal \& Belsham, 2013). Due to this reason, the vaccination programme is much challenging against this disease. FMD outbreak occurs all over Nepal irrespective of the climatic condition and altitude, however it occurred mostly during premonsoon ( April- May) and post-monsoon (Oct-Nov) period (Ferris et al., 1992).

\section{Causative Agent}

Foot and Mouth Disease (FMD) is caused by FMD virus which is a filterable virus of genus apthovirus and family Picornaviridae (Adhikari et al., 2018; Chakrabarti, 2017). It is a positive sense single stranded RNA virus. Seven different serotypes of FMD virus have been known, namely, A, O, C, SAT1, SAT2, SAT3 and Asia 1(Grubman \& Baxt, 2004)). Virulence and pathogenicity of FMDV differ among serotypes because of the variation caused by mutation, well known for single stranded RNA viruses (Callis \& Gregg, 2017). However, serotype O, A and Asia1 are predominant in Nepal. From 1965-2010, O is the most predominant serotype $(76.4 \%)$ in Nepal followed by Asia $1(15.8 \%)$, A $(6.5 \%)$ and C (1.2\%). Serotype C was observed only during the period from 1990-1996. From 2001 to 2010 serotype $\mathrm{O}$ is in increasing trend (82\%) followed by serotype Asia $1(15 \%)$ and serotype A (3\%) (Jha, 2012).

\section{Transmission}

FMD virus is present in all secretions and excretions of infected animal i.e. saliva, semen, milk, urine, faeces (Chakrabarti, 2017). Virus can easily transmit from the newly introduced infected animal in a herd through direct contact and it can also be transmitted via ingestion of contaminated milk and meat products, through direct contact with infected pens/buildings or contaminated animal transport vehicles, contaminated materials such as hay, feed, water, milk or biologics, contaminated clothing and foot wares (Chakrabarti, 2017).

In Nepal (1975), elephants made travel to Kathmandu from terai by foot in two weeks' time, as result of travelling in contaminated foot from water buffalo suffering from FMD, out of 30 animals, 16 elephants were recorded catching FMD (Pyakural et al., 1976). Livestocks movement within a country, mostly during festival seasons Dashain and Tihar, Legal and illegal trading of animals between India and Nepal are major factors supporting to the high frequency of outbreak of FMD in Nepal(Ferris et al., 1992).

\section{Pathogenesis}

Pathogenesis depends on different factors like the age of animal, species, strain of virus, the exposure dose and the immunity of host. Morbidity can reach $100 \%$ in susceptible populations. Mortality is generally low in adult animals (1$5 \%$ ), but higher in young calves ( $20 \%$ or higher). Infection of FMD occurs via ingestion or inhalation, direct or indirect with infected animals or their secretions and excretions like milk, urine, semen and faeces. Infection can also occurs from abrasions on mucus membrane of skin (Grubman \& Baxt, 2004).

Pathogenesis of FMD includes 4 different stages, previremia, establishment of viremia, viremia and post viremia. Pre-viremia is the period between infection and up to which the virus is first detected in blood (intravascular route) with quantitatively increasing trend which can be determined by viral isolation or viral RNA detection (Arzt et al., , 2011). Initial replication of virus takes place in the epithelium of upper respiratory tract, pharyngeal area and affect the mucus membrane of oral cavity and develop primary vesicles around tongue leading to the establishment of viremia. From primary lesions virus invade the lymphatics and then blood circulation resulting viremia. Now FMDV is widely distributed to epithelium of oral cavity, feet and udder and other visceral organs (Chakrabarti, 2012). There is the presence of FMDV also in secretions and excretions. Sometime gross lesions are noticed on myocardium in younger calves (Arzt et al., 2011) and heat muscles undergoes degeneration resulting in stripped appearance termed as "tiger heart" (Chakrabarti, 2012). Post viremia follows viremia starting with first negative assay of blood that includes resolutions of clinical signs, short term persistence of infectious virus, antigen or RNA in specific tissues, and sometime hirsutism, panting and thyroid disfunctions (Arzt et al., 2011).

\section{Global Situation}

FMD disease was first described in 1514 by Hieronymus Fracastorius, Italian monk in Venice (Jamal \& Belsham, 2013). In 1898, Loeffler and Frosch discovered that the causative agent of FMD is filterable virus (Jamal \& Belsham, 2013; Pattnaik et al., 2012). This disease is enzootic in South America, Central Europe, certain African countries like Ethiopia, and Tanzania. Countries like North America, UK, Australia and New Zealand are free from FMD. Australia is free from FMD since 1872 (Pattnaik et al., 2012). United states has been free from FMD since 1986. FMD is widely prevalent in Asian countries like India, Sri Lanka, Burma and Nepal. Incidence of FMD in Bangladesh and Pakistan is reduced because of adoption of eradication campaign. (Chakrabarti, 2017). Major epidemic of FMD occurred in the UK in 2001 and was caused by serotype O "pan Asia" strain of the FMDV. Over 6 million cows and sheep were killed with economic loss of around 4-5 billion US \$. Last outbreak had been in 1967. Because 
of highly contagious and infectious nature, FMD possess a great concern in term of agroterrorism .

Serotypes of FMD are not distributed in uniform manner worldwide. Serotype O and A are the most prevalent one globally(Valarcher et al., 2009). According to Pattnaik et al., 2012 Serotype $\mathrm{O}$ is causing outbreak in disease free countries while serotype A has greater geographical spread. The cumulative incidence of FMDV serotypes $(\mathrm{O}, \mathrm{A}, \mathrm{C}$, SAT-1, SAT-2, SAT-3) have occurred in Africa, whereas four serotypes( O , A , C and Asia-1) in Asia and Europe and three serotypes (O, A and C) been occurred in South America (Pattnaik et al., 2012; Valarcher et al., 2009). There were not any reported outbreaks in South America since 2013 and No serotype C outbreaks since 2004 which was last detected in Kenya and Brazil (FAO, 2017) (Fig. 1).

\section{Situation of FMD in Nepal}

Nepal is an agricultural country, more than $66 \%$ of Nepalese population is engaged on agriculture. Livestock plays an integral role contributing $31 \%$ to AGDP and about $13 \%$ to GDP. FMD susceptible livestock are cattle, buffalo, goat, sheep and pig with population of 7.02 million, 4.68 million, 4.2 million, 0.80 million and 1.04 million respectively, so the overall livestock population is around 22.16 million (MOLD, 2016). Species wise distribution of FMD outbreaks from 2000-2009 was highest in cattle(42\%) followed by buffaloes(32\%), goats(19\%), sheep(4\%) and 3 $\%$ in swine (Jha, 2016) FMD is endemic in Nepal causing substantial economic losses to livestock sector (Adhikari et al., 2018). Around 66 million US \$ is estimated economic loss due to FMD (Jha, 2012) however the actual loss could be much higher. The losses mainly due to reduction in milk production is estimated to be NRS 94806 ( MOLD, 2016) . Also, Being a member of the World Trade Organization
(WTO), the presence of FMD in the country is a barrier to international trade of livestock and animal (Ferris et al., 1992). Out of seven different serotypes of FMD virus, serotype O, A and Asia-1 are predominant in Nepal. strain $\mathrm{O}$ had the highest prevalence of $81 \%$ followed by strain Asia-1(11\%), A (6\%) and C (3\%). Serotype C was not detected after 1996 and after 2012 only serotype O was detected (Jha, 2012). From 2012 to 2015, there was only FMD Serotype, O, reported in Nepal, however, during 2016, there was one outbreak of FMD serotype A in Chitwan and one outbreak of FMD serotype Asia-1 in Kaski (WRLFMD, 2018). There was involvement of FMDV serotype $\mathrm{O}$ in $>80 \%$ of the outbreaks (Adhikari et al., 2018).

Year-wise distribution of FMD outbreaks in Nepal during the period of 2001-2015, shows that, highest outbreak was observed in the year 2003 and the number of outbreaks was 2078.Similarly 1903 outbreak was recorded in year 2001 . Large number of outbreak during these year might be due to the involvement of high virulent pan Asia strain of serotype 'O'(Veterinary Epidemiological Center, 2016). During 2001/03, Nepalese dairy products were not allowed to enter China because of the presence of FMD in Nepal (VEC, 2016a).

Similarly, month-wise distribution of FMD outbreak during the same period of 2001-2015 shown in Fig. 2 shows that, highest number of outbreak was recorded during premonsoon and monsoon period( May-August), although FMD outbreak occurs throughout the year due to excessive movement of animals for agricultural operation which contributes the spread of disease lead to more outbreak (Ferris et al., 1992; Veterinary Epidemiological Center, 2016).

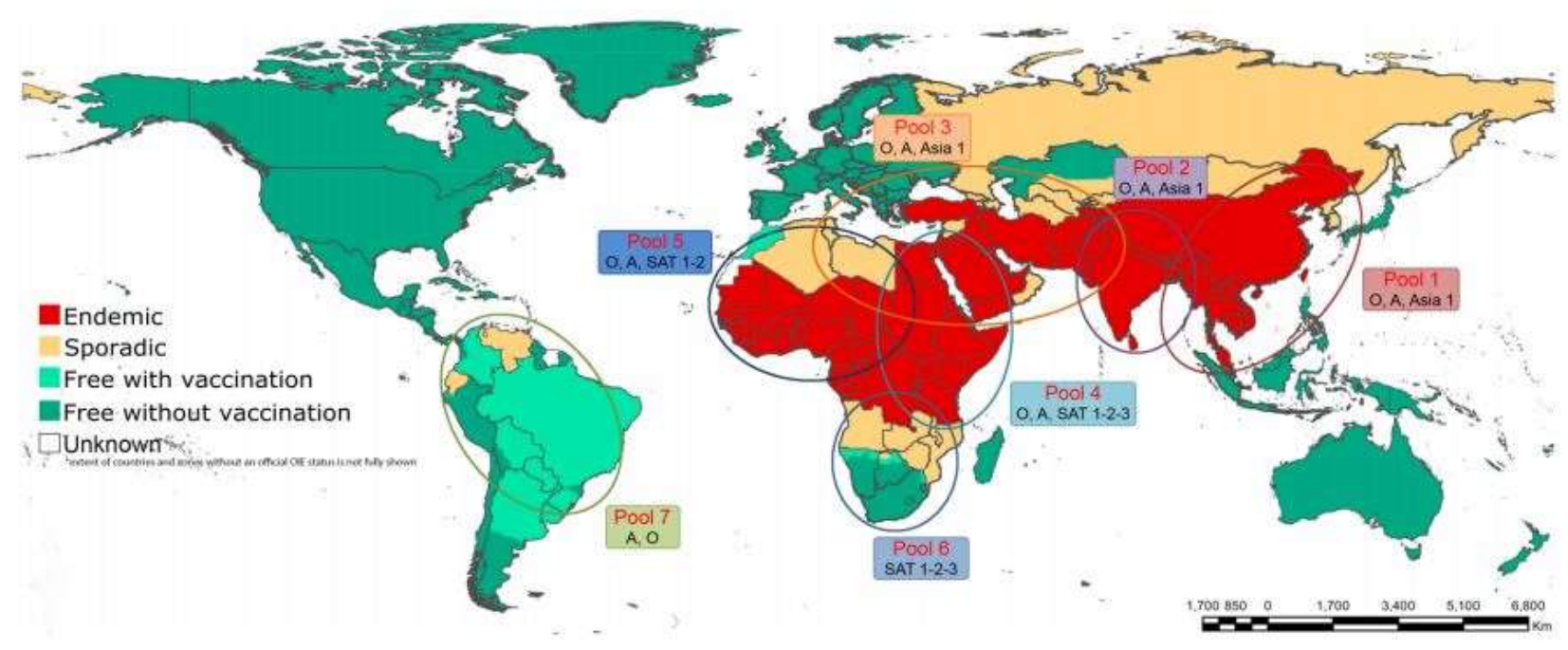

Fig. 1: Distribution of the seven endemic pools of FMD showing status of FMD in countries. Source: (FAO, 2017) 


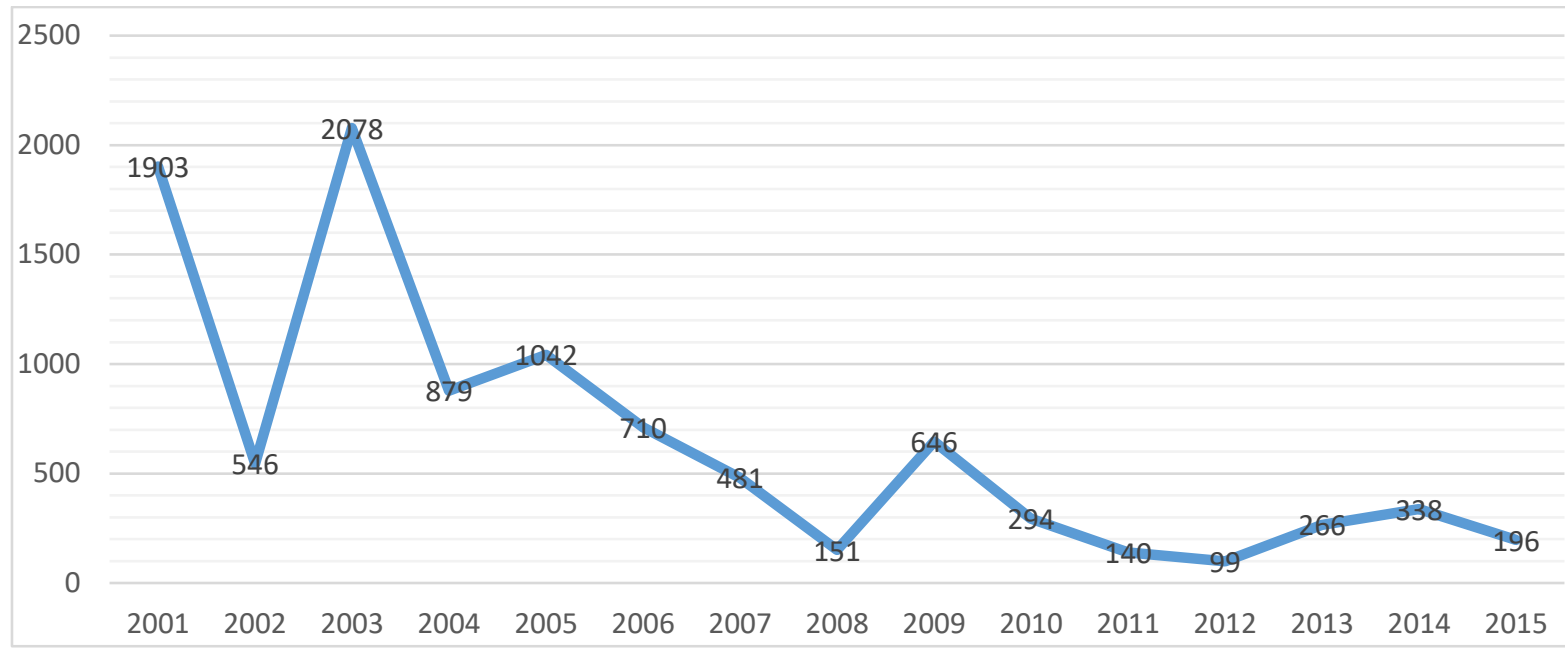

Fig. 2 : Year-wise distribution of FMD outbreaks in Nepal during the period of 2001-2015. Source: (VEC, 2015)

Table 1: Ecozones-wise distribution of FMD

\begin{tabular}{|l|l|l|l|}
\hline Ecozones & No. of Outbreaks & No. of animal infected & No. of death \\
\hline Mountain & 1955 & 74582 & 1094 \\
\hline Hill & 4472 & 188275 & 3663 \\
\hline Terai & 3342 & 103524 & 2106 \\
\hline
\end{tabular}

Source: (VEC, 2015)

Table 2: Development region wise distribution of FMD

\begin{tabular}{|l|l|l|l|}
\hline Development Region & No. of Outbreaks & No. of animal infected & No. of death \\
\hline Eastern & 1011 & 39692 & 362 \\
\hline Central & 2253 & 65588 & 2805 \\
\hline Western & 2216 & 72882 & 1415 \\
\hline Mid-Western & 2109 & 92104 & 1318 \\
\hline Far-Western & 2180 & 96115 & 1415 \\
\hline
\end{tabular}

Source: (VEC, 2015)

Distribution of FMD by eco-zones (2001-2015) as mentioned in Table 1 shows that FMD outbreak was recorded highest in hilly region i.e. 4472 followed by Terai i.e. 3342 and Mountain i.e. 1955. Highest outbreak in hilly region might be due to the presence of highest number of ruminants population(Veterinary Epidemiological Center, 2016).

Similarly, Table 2 shows development region wise distribution of FMD. The highest outbreak occurred in Central Development Region (9769 outbreak) due to the presence of large number of livestock population and lowest outbreak was recorded in Eastern Development Region i.e.
1011, because of FMD control program launched there since EDR is a dairy pocket area of Nepal.

District wise distribution FMD outbreak between 20012015, shows that, highest outbreak of FMD was observed in Achham (672), Dang (542), and Bajhang (505) similary lowest outbreak, less than 10 was observed in Solukhumbu (7) , Taplejung (6), Panchthar (6), and Okhaldhunga (5).Cattles were most frequently affected followed by buffalo, goat, sheep and pig(Veterinary Epidemiological Center, 2016).

The Table 3 shows the six-month report of FMD outbreak in the year 2016 between January-16 to June-16. 
Table 3: Eco-zone wise distribution of FMD

\begin{tabular}{|l|l|l|l|l|l|l|}
\hline $\begin{array}{l}\text { Eco- } \\
\underline{\text { Zones }}\end{array}$ & $\begin{array}{l}\text { No of } \\
\text { outbreaks }\end{array}$ & $\begin{array}{l}\text { No of } \\
\text { susceptible }\end{array}$ & $\begin{array}{l}\text { No of } \\
\text { affected }\end{array}$ & $\begin{array}{l}\text { No of dead } \\
\text { animals }\end{array}$ & $\begin{array}{l}\text { No. of } \\
\text { vaccinated }\end{array}$ & $\begin{array}{l}\text { No. of } \\
\text { treated }\end{array}$ \\
\hline & 117 & 48393 & 5541 & 237 & 356378 & 5304 \\
\hline Mountain & 13 & 3470 & 93 & 4 & 15322 & 89 \\
\hline Hill & 70 & 3906 & 3336 & 114 & 128391 & 3222 \\
\hline Terai & 34 & 41017 & 2112 & 119 & 212665 & 1993 \\
\hline
\end{tabular}

Source: (VEC, 2016b)

Recently at Bageshwari Gaushala, Chitwan, 80 cattle out of 150 were infected by FMD virus and presence of ' $O$ ' serotype was confirmed by National FMD and TAD laboratory by PCR(Milan Kandel, Sachin Regmi, Bablu Thakur, Ramchandra Acharya, \& Krishna Kaphle, 2018).

New strain of serotype 'A' G-VII was detected in Chitwan district in 2017. 17 cattle and 3 buffalo were infected however mortality was 0\% (WRLFMD, 2018).

\section{Diagnosis}

Diagnosis is based on history, clinical signs and symptoms like vesicles on oral cavity, teat region and hooves, lameness etc. Animal suspected for FMD showing lameness, fever and salivation are kept under close observation for 6 hours and during this period in positive cases there will be appearance of foot and mouth lesions. We may get confused with other disease like malignant catarrhal fever, mucosal disease, rinderpest and vesicular stomatitis so laboratory diagnosis is necessary. Due to rapid spread and serious consequences resulting from FMD, specific and sensitive laboratory diagnosis is needed to detect the particular serotype of virus (Jamal \& Belsham, 2013). Neutralization test, Enzyme linked immunosorbent assay (ELISA), Compliment Fixation Test, Animal Inoculation, Agar Gel Diffusion Precipitation Test, Fluorescent Antibody Test, Tissue culture and Chromatographic strip test are various techniques used worldwide for diagnosis of FMD (Chakrabarti, 2017; Ferris et al., 1992); Jamal \& Belsham, 2013).

In Nepal indirect sandwich antigen- ELISA (antigen and antibody) method is widely used for the identification of serotypes of FMD virus (Ferris et al., 1992). However, PCR (Conventional \& Real Time) is also used (Adhikari et al., 2018; Ferris et al., 1992). Performance is according to manufacturer's instruction.

\section{Treatment}

There is no specific treatment. Symptomatic treatment is done depending on clinical manifestations. Antiseptic solutions along with potassium permanganate and glycerene may applied over oral lesions. Fluid therapy is preferred is severely affected cattle. Pyrexia can be treated by administrating meloxicam-paracetamol combination, 0.5 $\mathrm{mg} / \mathrm{kg}$ body wt., I/M (Kandel et al., 2018). Aloe-Vera gel can be applied to the oral wound after cleaning, which speeds up wound healing and reduce the inflammation ( Kandel et al., 2018). In Kikuyu district of Kenya, out of 166 cattle, 95 were affected by FMDV. Natural Soda ash solution (sodium bicarbonate 95\%) was used for washing the lesions followed by the application of raw honey and finger millet flour to the cleaned lesion, rapid healing was observed after 3 days (Gakuya et al., 2011). Other various ethnoveterinary remedies used includes onion, garlic, turmeric, coriander etc. for treatment of vesicular and blisters like lesions (Tiwari et al., 2009).

\section{Prevention and Control}

FMD is highly contagious viral disease affecting livestock throughout the world, although mortality is low but outbreak results in greater economic loss so the prevention and control measures is must. Control measure varies from country to country depending upon their financial status. limited approaches are used in Asian and African countries because of high cost of vaccines and limited slaughter practices and religious grounds whereas, developed countries carry out large scale vaccination programs, slaughtering of infected animals and strict quarantine practices. For efficient control of FMD, regular vaccination and restriction of the movement of infected animal and their products as well, are crucial (Pattnaik et al., 2012). The global FMD control strategy Progressive control pathway for foot and mouth disease (PCP-FMD) was developed by FAO and further endorsed by OIE, which has five stage approach to control FMD. This strategy recognizes, guides and manage the risks of FMD, in endemic countries, step by step.

Due to religious belief, test and slaughter of infected cattle is not practiced in Nepal. Main way of disease prevention and control is through vaccination. The quadrivalent vaccine of serotype (O, C, A and Asia-1) was introduced in Nepal in 2010 (Adhikari et al., 2018), since the most prevalent serotypes in Nepal are O, A, and Asia-1 (Adhikari et al., 2018). The vaccination against one serotype does not provide cross protection against other (Jamal \& Belsham, 2013). Due to this reason, the vaccination programme is much challenging against this disease. Ring vaccination is carried out to susceptible livestock around the region where outbreak occurred. FMD control program at a national level 
was implemented in 2011. 10 districts of Eastern Development Region of Nepal were selected for FMD control as a pilot area where mass vaccination was carried out. In 2016, French Ambassador, Martine Bassereall, visited Nepal to attend a program, to administer the vaccine against FMD in Bhaktapur district, donated 100000 dozen of FMD vaccine to Nepal government (VEC, 2016a). The first dose of vaccine against FMDV should be administrated at four months of age and above, followed by booster dose, one month after the first and subsequent doses once every six months ( Adhikari et al., 2018; Kandel et al., 2018).Also Real time FMD training has been running in Nepal since 2012, and around 120 Nepalese Veterinarians, 250 Australian and some New Zealand veterinarians have been trained so far. Upcoming training course is going to be held on Nov-29 and then on Dec-6, 2019 (FAO, 2017).

\section{Vaccination Schedule Practiced in Nepal}

Vaccination schedule of Formalised Almunium hydroxide gel vaccine (Raksha vaccine) is shown in Table 4. Similarly, Vaccination schedule of Oil adjuvant vaccine (RakshaOvac) is shown in Table 5.

Table 4: Vaccination schedule of Formalised Almunium hydroxide gel vaccine (Raksha vaccine).

\begin{tabular}{|l|l|l|}
\hline & Calves & Adults \\
\hline $\mathbf{1}^{\text {st }} \mathbf{d o s e}$ & 4 months & At any age \\
\hline $\mathbf{2}^{\text {nd }}$ dose & $\begin{array}{l}\text { After 4 weeks of } 1^{\text {st }} \\
\text { dose }\end{array}$ & $\begin{array}{l}\text { After 4 weeks of } 1^{\text {st }} \\
\text { dose }\end{array}$ \\
\hline $\begin{array}{l}\text { Booster } \\
\text { dose }\end{array}$ & $\begin{array}{l}\text { Once every } 6 \\
\text { months }\end{array}$ & $\begin{array}{l}\text { Once every } \\
\text { months }\end{array}$ \\
\hline
\end{tabular}

Table 5: Vaccination schedule of Oil adjuvant vaccine (Raksha-Ovac).

\begin{tabular}{|l|l|l|}
\hline & Calves & Adults \\
\hline $\mathbf{1}^{\text {st }} \mathbf{d o s e}$ & 4 months & At any age \\
\hline $\mathbf{2}^{\text {nd }} \mathbf{d o s e}$ & After 9 months & After 9 months \\
\hline Booster dose & Annually & Annually \\
\hline
\end{tabular}

Source: National FMD and TAD laboratory

\section{Conclusion}

FMD is a serious problem in developing country like Nepal where livestock is the major agribusiness sector (Ferris et al., 1992). Although the mortality rate is low, morbidity rate and frequency of outbreak is very high due to its high contagious nature. FMD is endemic in Nepal since long year back, occurring throughout the year, leading to high economic loss of about 66 million US dollar per year (Jha, 2012). The most prevalent serotype is ' $O$ ' however serotypes ' $A$ ' and 'Asia-1' have also been detected repeatedly. Movement of animals within the country mainly during festival seasons, Illegal trading of livestock between Nepal and India because of open border, poor knowledge about the disease among farmers, high cost of treatment and control, lack of strict quarantine practices, poor biosecurity approach etc. are major factors contributing to the high frequency of outbreak. So, regular vaccination and restriction of the movement of infected animal is essential for the control and prevention of disease.

\section{Author's Contribution}

All authors equally contributed in all stages of research works and finalization of manuscript.

\section{Conflict of Interest}

The authors declare that there is no conflict of interest with present publication.

\section{References}

Adhikari G, Acharya KP, Upadhyay M, Raut R, Kaphle K, Khanal T \& Arzt J (2018) Outbreak investigations of foot and mouth disease virus in Nepal between 2010 and 2015 in the context of historical serotype occurrence. Veterinary medicine and science 4(4): 304-314. DOI: $\underline{10.1002 / \mathrm{vms} 3.120}$

Kandel M, Regmi S, Thakur B, Acharya R \& Kaphle K (2018) Foot-and-Mouth Disease Outbreak at Bageshwori Gaushala, Chitwan, Nepal. Journal of Agricultural Science and Technology A 8(6). DOI: 10.17265/2161$\underline{6256 / 2018.06 .008}$

Arzt J, Juleff N, Zhang Z \& Rodriguez LL (2011) The pathogenesis of foot-and-mouth disease I: viral pathways in cattle. Transboundary and emerging diseases 58(4): 291-304. DOI: 10.1111/j.1865-1682.2011.01204.x

Adhikari S (2018) Evaluation of Economic Losses due to FMD in Livestock in Chitwan District (Nepal). 2(8): 3-7.

Brito BP, Rodriguez LL, Hammond JM, Pinto J \& Perez AM (2017) Review of the global distribution of foot-andmouth disease virus from 2007 to 2014. Transboundary and emerging diseases 64(2): 316-332. DOI: $\underline{10.1111 / \text { tbed.12373 }}$

Ferris NP, Donaldson AI, Shrestha RM, \& Kitching RP (1992) A review of foot and mouth disease in Nepal. Revue Scientifique Et Technique-Office International Des Epizooties 11: 685-685. DOI: $\underline{10.20506 / \text { rst.11.3.625 }}$

Gakuya DW, Mulei CM \& Wekesa SB (2011) Use of ethnoveterinary remedies in the management of foot and mouth disease lesions in a dairy herd. African Journal of traditional, complementary and alternative medicines 8(2). DOI: 10.4314/ajtcam.v8i2.63204

Grubman MJ \& Baxt B (2004) Foot-and-mouth disease. Clinical microbiology reviews 17(2): 465-493. DOI: 10.1128/CMR.17.2.465-493.2004

Jamal SM \& Belsham GJ (2013) Foot-and-mouth disease: past, present and future. Veterinary research 44(1): 116. DOI: $\underline{10.1186 / 1297-9716-44-116}$ 
Pattnaik B, Subramaniam S, Sanyal A, Mohapatra JK, Dash BB, Ranjan R \& Rout M (2012) Foot-and-mouth disease: global status and future road map for control and prevention in India. Agricultural Research 1(2): 132-147. DOI: $10.1007 / \mathrm{s} 40003-012-0012-\mathrm{Z}$

Valarcher JF, Knowles NJ, Zakharov V, Scherbakov A, Zhang Z, Shang YJ \& Tosh C (2009) Multiple origins of foot-andmouth disease virus serotype Asia 1 outbreaks, 20032007. Emerging infectious diseases 15(7): 1046. DOI: $\underline{10.3201 / \text { eid1507.081621 }}$

Jamal, S M, \& Belsham, G J (2013) Foot-and-mouth disease: past, present and future. Veterinary research, 44(1), 116. DOI: $\underline{10.1186 / 1297-9716-44-116}$

Chakrabarti, A (2017) A text book of Preventive Veterinary Medicine. New Delhi: Kalyani.

Veterinary Epidemiological Center (2016) Annual Epidemiological Bulletin-2016

Livestock Statistics of Nepal (2017) Singhadurbar, Kathmandu, Nepal: Government of Nepal.

VEC (2015). Annual Epidemiological Bulletin, Veterinary Epidemiology Center, Nepal. Retrieved Sep, 17, 2019, , from http://epivet.gov.np/uploads/files/6021247917.pdf.
VEC (2016a). "FMD newsletter quarterly bulletin”. Retrieved 21 Sep, 2019 from http://epivet.gov.np/uploads/files/0292208658.pdf.

VEC (2016b). "Six-monthly epidemiological bulletin JanuaryJune 2016". Retrieved Sep, 19, 2019 from http://www.epivet.gov.np/uploads/files/4332702382 .pdf.

WRLFMD (2018) "FMDV genotyping Nepal”. Retrieved Sep, 20, 2019 ,

from http://www.wrlfmd.org/fmd_genotyping/asia/nep.ht $\underline{\mathrm{m}}$

MOLD (2016) Annual Report, Ministry of Livestock Development, Government of Nepal. Retrieved Sep, 17, 2019 ,

from http://www.mold.gov.np/downloadfile/Mold_Annu al_Report_Inner_mold.pdf

Jha VC (2012) "Situation of foot and mouth disease and its progressive control initiatives in Nepal". Retrieved Sep, from http://www.fao.org/docs/eims/upload/299831/an359 e00.pdf

Gongal GN (2002) Foot and mouth disease in Nepal. Technical Report Kathmandu, Nepal, National FMD Control Section.1, 19-22 